\title{
Implementation of the Teaching of Economic Management Specialty in the Background of Internet+ Based on Smart Agent
}

\author{
Chao Zhang' and Xiaoyu Hang $\mathbb{D}^{2,3}$ \\ ${ }^{1}$ Economics and Business Management School, Tianjin Sino-German University of Applied Sciences, Tianjin 300350, China \\ ${ }^{2}$ Department of Economics and Trade, Tianjin University of Commerce Boustead College, 300384 Tianjin, China \\ ${ }^{3}$ School of Finance, Central University of Economics and Finance, 102206 Beijing, China
}

Correspondence should be addressed to Xiaoyu Hang; xh21@caa.columbia.edu

Received 26 October 2021; Revised 11 November 2021; Accepted 20 December 2021; Published 27 February 2022

Academic Editor: Punit Gupta

Copyright (C) 2022 Chao Zhang and Xiaoyu Hang. This is an open access article distributed under the Creative Commons Attribution License, which permits unrestricted use, distribution, and reproduction in any medium, provided the original work is properly cited.

\begin{abstract}
Today is the age of information and networks. In the context of the Internet, our country's economy is growing rapidly. However, given the current state of economic governance, traditional courses and educational models can no longer be applied. It is necessary to combine the content of teaching materials, the needs of social development, and the current situation of students to carry out reforms and innovations to deepen and promote the overall development of basic education in our country. This article mainly introduces how to refer to literature surveys, analysis-level processes, and questionnaire survey. In this article, we will use Internet+ to study the application of specialized education in economic management and create possible mathematical models. The model is resolved through a process in the analysis hierarchy, the application and research status of economic management education is evaluated, and the accuracy of assessing the implementation status of economic management education is evaluated. Results show that the process of analytical hierarchy increased the effectiveness of conducting economic management education by $13 \%$ and reduced the rate of false positives. Finally, the system explains the impact of Internet+ on the implementation of economic management by comparing the analysis of problems existing in the education of economic management courses on the Internet with the analysis of the satisfaction level of practical education of economic management courses. The survey results show that the professional practice research of comprehensive professional training and compulsory professional courses needs improvement.
\end{abstract}

\section{Introduction}

Education is the foundation of national revitalization. To achieve sustainable development of our economy, we must strengthen the quality of education [1], encourage the abilities and skills of all students, increase their enthusiasm and motivation, and lay the foundation for the sound development of the national economy $[2,3]$. Teaching an economic management course is very important in today's information society and knowledge economy [4]. From a scientific point of view, rationalization can only be achieved by understanding this knowledge and continuously developing the latest courses [5]. Combining student experience can improve science, for example, the development of professional talent, the innovation of science and technology, and the contribution to the economic development of the country $[6,7]$. A large amount of data was collected in this study to evaluate the framework of this study. This case study demonstrates the importance of Internet+ for implementing economic management education and system implementation $[8,9]$. However, the process of collecting messages is so complex that the results of the data are not very accurate. Based on research on the application of economic management training in the context of Internet+, educational applications for key parts of economic management are being studied via Internet + . A method has been established for calculating procedures in the analytical hierarchy combined with a bibliographic. 


\section{Implementation Research Methods of Economic Management Professional Teaching under the Background of Internet+}

2.1. AHP. Mathematical methods are used to convert the relative importance of each index into weights and classify the various decision shapes to find the best decision shape. We then proceed to normalize the importance of each evaluation factor, that is, the range of functions required to classify weight values $[10,11]$. The test uses the following formula:

$$
Q_{A}=\gamma_{\max } A,
$$

where $\gamma_{\max }$ is the largest feature root of $Q_{A}$ and $W$ is the normalized feature vector corresponding to $\gamma_{\max }$.

The randomization rate of the table is represented by EI. The general index of the evaluation table is represented by $M$.

$$
\mathrm{EI}=\frac{\left(\gamma_{\max }-M\right)}{(M-1)} \text {. }
$$

The basic principle of analytic hierarchy process is that analytic hierarchy process systematically absorbs research material and makes decisions based on variations, comparisons, evaluations, and complex thinking [12]. This method is especially useful for evaluating unstructured systems and for systems with multiple properties, multiple criteria, and time periods. Not only is this method suitable for high-level statistics but it also focuses on powerful, highquality models for processing behaviors, thoughts, concepts, and complex systems to coordinate human thinking advancement. This method is combined with accepting and adjusting various practical, general, and difficult scenarios, which are difficult to compare with decisions on many issues at the same level. The calculations are easy, and the results found are easy for decision makers to understand.

2.2. Investigation and Research Method. This article conducts a comprehensive investigation, analysis, synthesis, comparison, and summary of the current situation and reasons for the formation of party member ideology and policies in the traditional and new media era. The large amount of data collected through the survey can improve the professional teaching of how to comprehensively construct and deeply understand business management in the Internet era.

\section{Implementation Research Experiment of Economic Management Professional Teaching under the Background of Internet+}

\subsection{Experimental Design of Practical Teaching System for} Economic Management Majors. Economics and management belong to the applied research disciplines of applied economics and management. Students should have basic knowledge and basic professional theories and be able to use the knowledge gained in practice to improve their practical ability. Therefore, how to enhance and improve the level of practical education of financial management graduates has become an important issue of current university development. In order to determine the system of professional financial management practice, the research team visited relevant companies and investigated employment trends.

In the questionnaire, the professional management system of professional management skills is divided into four levels: professional basic knowledge, professional operation skills, professional comprehensive training, and professional research skills. These four levels are progressive, so students can be trained at various levels. Through training, students establish a sound economic management professional knowledge system and gradually increase comprehensive professional skill and will eventually develop into excellent economic management professionals.

\subsection{Experimental Data Collection of Practical Teaching} System for Economic Management Majors. For effective performance analysis, this article studies positions in commercial banks, securities companies, companies, and manufacturing and processing companies. Through seminars and other methods, 200 undergraduates and students in the field of economic management were organized. After this study identified the skills students need to stay in the workplace, we opened courses to improve the knowledge of each skill. After analyzing the results, it is said that the useful research results obtained are comparable to the results of interviews with economic and administrative leaders. The data results are shown in Table 1.

It can be seen from Table 1 that the average scores of professional basic knowledge, professional operating skills, professional comprehensive training, and professional research and practice before graduation are 10, 9, 6 , and 5 points higher than the exam results after graduation, which shows that the four aspects of professional basic knowledge, professional operating skills, professional comprehensive training, professional research and practice are of great significance to economic management. Professional students are very important. For students majoring in economics and management after graduation, it reflects that basic professional knowledge, professional operating skills, professional comprehensive training, professional research and practice are indispensable skills among many skills. To help the readers better understand the three relationships, the results are shown in Figure 1.

It can be seen from Figure 1 that the four majors necessary for economic management students are professional basic knowledge, professional operating skills, professional comprehensive training, and professional research practice. Before and after graduation, students' cognition of these four skills has changed from shallow to deep, which shows that the implementation of the teaching of economics and management majors needs to improve students' ability to have the skills necessary for the major deep knowledge. 
TABLE 1: Statistics on the ability of economic management students.

\begin{tabular}{lcccc}
\hline Grading & $\begin{array}{c}\text { Professional basic } \\
\text { knowledge/point }\end{array}$ & $\begin{array}{c}\text { Professional operation } \\
\text { skills/point }\end{array}$ & $\begin{array}{c}\text { Professional comprehensive } \\
\text { training/point }\end{array}$ & $\begin{array}{c}\text { Professional research } \\
\text { practice/point }\end{array}$ \\
\hline $\begin{array}{l}\text { Test average score before } \\
\text { graduation }\end{array}$ & 78 & 88 & 79 & 86 \\
$\begin{array}{l}\text { Test standard deviation before } \\
\text { graduation (X0.01) }\end{array}$ & 25 & 32 & 14 & 24 \\
$\begin{array}{l}\text { Test average score after } \\
\text { graduation }\end{array}$ & 88 & 97 & 85 & 91 \\
$\begin{array}{l}\text { Test standard deviation after } \\
\text { graduation (X0.01) }\end{array}$ & 12 & 31 & 12 & 20 \\
\hline
\end{tabular}

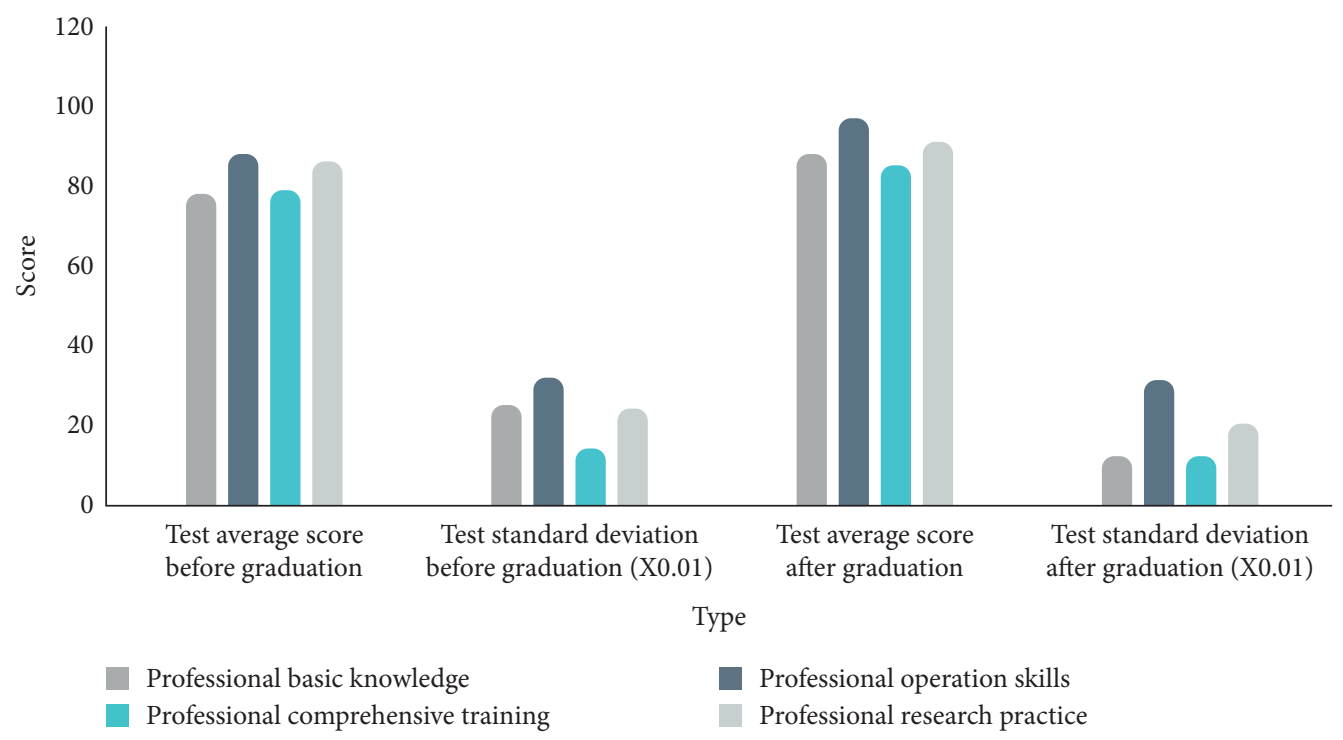

FIGURE 1: Statistics chart of ability data of economic management majors.

\section{Implementation of Economic Management Teaching under the Background of Internet+}

4.1. Problems Existing in the Teaching of Economics and Management Courses under the Background of the Internet. Under the influence of traditional thinking, the mentality of most teachers has not changed, and insight cannot be stimulated in this learning process. Direct teaching improves the quality of economic management skills training. In addition, in the curriculum, the teacher-centered way of thinking needs to be changed. Keeping an open mind should be a key part of the classroom so that they can actively participate in learning and use their theme initiatives and creativity to maximize the impact of classroom learning. At the same time, economics and management need to combine theory with practice, while the lack of economic research talents requires more in-depth improvement and innovation.

\subsection{Satisfaction Analysis of Economic Management Courses} Teaching Practice Arrangement. Courses analyzed include basic knowledge of business and management-students, business, accounting management, marketing, human resource management, operational skills, professional training in business management, business management and school environment, network marketing, e-commerce economic management, property evaluation, international regulations, and other practical training. management; property evaluation; international regulations and other practical training. Through management types, sales management, project management, and business consulting courses, we teach students risk management and management skills and renew outdated business skills. Through the financial field training experience and manual operation enabled by the advanced educational financial sand table platform, the students can practice management skills of managing enterprises.

So far, this article has evaluated the satisfaction of education provided in economic management courses, the satisfaction of extensive training, and the satisfaction of practical research. The data results are shown in Table 2.

From Table 2 ,in response to the question "Are you satisfied with the order of the official's practical courses?", $65 \%$ of the students believe that full-time job training is the objective of the required courses, while $75 \%$ of the students believe that the selected courses are not according to the intermediate training activities. Only $2 \%$ of students are dissatisfied with the vocational practice of learning required vocational courses, while the remaining $21.33 \%$ of students think it is appropriate and satisfactory. In other words, in the teaching system of practical courses, the number of satisfied students has not yet reached half of the total number of students surveyed. The analysis is shown in Figure 2. 
TABLE 2: Data of satisfaction with the arrangement of practical teaching courses for this major.

\begin{tabular}{lcccc}
\hline Course setting and implementation & $\begin{array}{c}\text { General compulsory } \\
\text { course (\%) }\end{array}$ & $\begin{array}{c}\text { General elective } \\
\text { course (\%) }\end{array}$ & $\begin{array}{c}\text { Major required } \\
\text { courses (\%) }\end{array}$ & $\begin{array}{c}\text { Professional elective } \\
(\%)\end{array}$ \\
\hline $\begin{array}{l}\text { Professional comprehensive training } \\
\text { satisfaction }\end{array}$ & 65 & 75 & 78 & 73 \\
$\begin{array}{l}\text { Professional practice research } \\
\text { satisfaction }\end{array}$ & 78 & 88 & 65 & 81 \\
Course schedule satisfaction & 86 & 95 & 83 & 72 \\
\hline
\end{tabular}

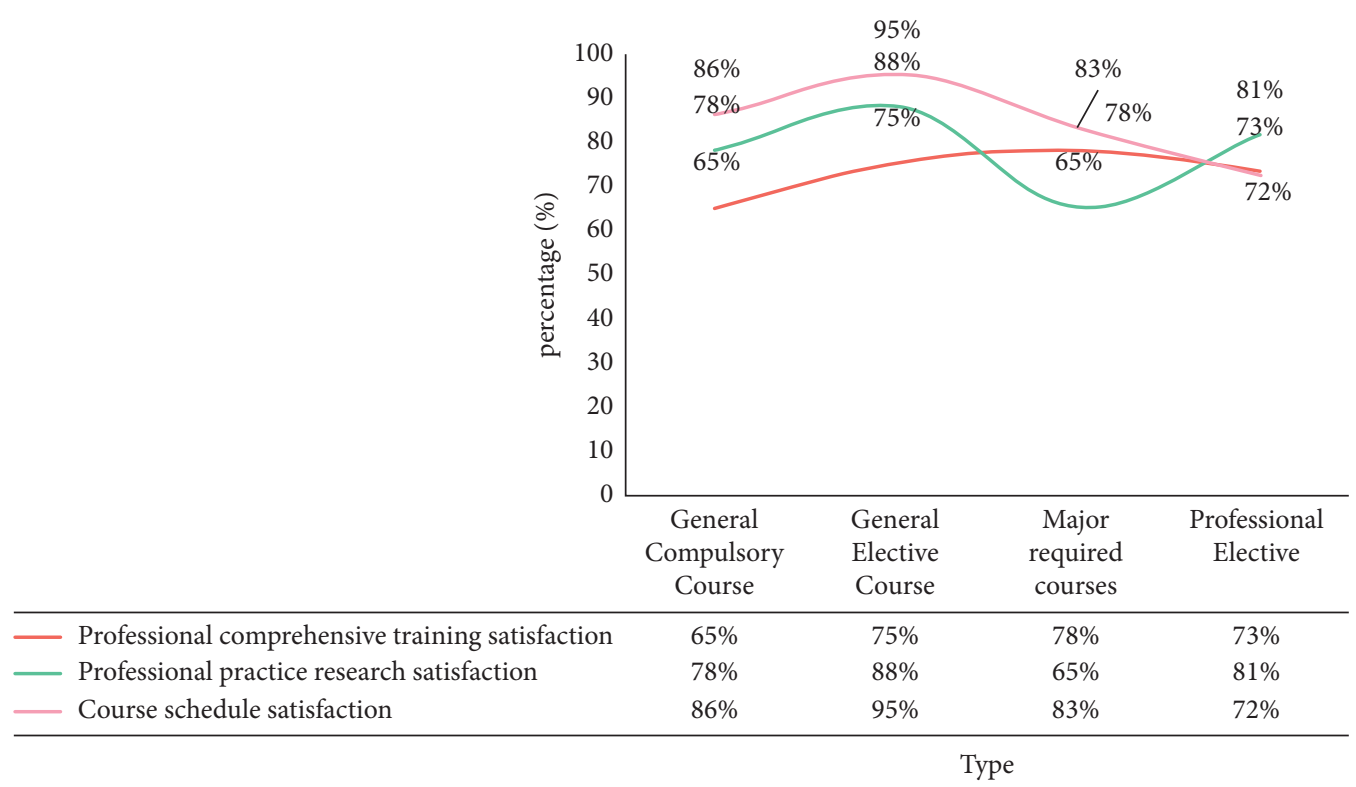

FIgURE 2: Data graph of satisfaction with the arrangement of practical teaching courses for this major.

From Figure 2, it can be seen that the professional comprehensive training satisfaction of general compulsory courses, the professional comprehensive training satisfaction of general elective courses, the satisfaction with the professional practice research of the compulsory professional courses, and the curriculum arrangement of the professional elective courses are the lowest. From then on, it can be seen that the economic management course teaching practice curriculum is set and implemented in the professional comprehensive training of the general compulsory courses and the general elective courses. The professional practice research of comprehensive professional training and compulsory professional courses needs improvement.

\section{Conclusions}

In this article, we did some research on bibliographic reference research methods, analytical hierarchical procedures, and research methods, but they still have many drawbacks. There are also many comprehensive results and research methods on the implementation of financial education and management on the Internet. Therefore, we can learn from existing methods when studying financial education and management. The system explains the impact of the Internet+ on the implementation of economic management by comparing the analysis of problems existing in the education of economic management courses on the Internet with the analysis of the satisfaction level of practical education of economic management courses. The survey results show that the professional practice research of comprehensive professional training and compulsory professional courses needs improvement.

\section{Data Availability}

No data were used to support this study.

\section{Conflicts of Interest}

The authors declare that they have no potential conflicts of interest with respect to the research, authorship, and/or publication of this article.

\section{Acknowledgments}

This study was supported in part by Tianjin Technical Expert Project (19JCTPJC44000), Tianjin Municipal Education Commission 2019 Scientific Research Project (2019SK123), and Tianjin Municipal Education Commission 2020 Scientific Research Project (2020SK142).

\section{References}

[1] N. Bilan, "The research of the motivation sphere of future electric power engineers to study foreign language," Professional Education: Methodology, Theory and Technologies, vol. 10, no. 10, pp. 9-24, 2019. 
[2] L. Yaroshevska, "Civic education of youth by means of musical art by V. Sukhomlinsky," Scientific Visnyk V.O. Sukhomlynskyi Mykolaiv National University. Pedagogical Sciences, vol. 65, no. 2, pp. 373-377, 2019.

[3] O. S. Pankrateva, Y. V. Yurova, P. K. Krylov, E. V. Zinoviev, D. O. Vagner, and L. M. Likhonos, "Errors in differential diagnosis of burn injury at the prehospital stage," Russian Sklifosovsky Journal "Emergency Medical Care", vol. 9, no. 4, pp. 659-665, 2021.

[4] S. Sarvepalli, D. Kumar, M. Lie et al., "S1235 pilot implementation of video telehealth for gastrointestinal sub-specialty care to veterans during the COVID-19 pandemic," American Journal of Gastroenterology, vol. 115, no. 1, Article ID S620, 2020.

[5] A. Tsyrulnik, K. Goldflam, R. Coughlin et al., "Implementation of a physician assistant emergency medicine residency within a physician residency," Western Journal of Emergency Medicine, vol. 22, no. 1, pp. 45-48, 2020.

[6] S. A. Rehman Khan, Y. Zhang, M. Anees, H. Golpîra, A. Lahmar, and D. Qianli, "Green supply chain management, economic growth and environment: a GMM based evidence," Journal of Cleaner Production, vol. 185, no. 1, pp. 588-599, 2018.

[7] W. Wu and C. Huang, "Research on the CAD/CAM technology teaching of the mechanical specialty of applied undergraduate university in the background of intelligent manufacturing," Science and Education, vol. 417, no. 3, pp. 50-52, 2018.

[8] O. Pylypenko and O. A. Yurchenko, "Improving the professional education of accountants for the effective operation of the economic security system at company level," Statistics of Ukraine, vol. 89, no. 2-3, pp. 148-154, 2020.

[9] Q. Wu and F. Yin, "Research on the construction of practical teaching system-a case study of management specialty in application-oriented university," Journal of Changchun Institute of Technology (Social Science Edition), vol. 17, no. 3, pp. 128-131, 2016.

[10] L. Ivanova and E. Lukomskaya, "On the implementation of the communicative approach in foreign language teaching of students in non-linguistic universities," Scientific Research and Development Modern Communication Studies, vol. 9, no. 1, pp. 47-52, 2020.

[11] L. Song, "On the implementation of experience teaching in "The Outline of Modern History of China"," Science and Education, vol. 369, no. 11, pp. 26-28, 2016.

[12] B. Behforouz and A. D. Frumuselu, "The reflection of vocabulary implementation through educational texting on EFL learner's reading skill," International Journal of Interactive Mobile Technologies (IJIM), vol. 15, no. 1, Article ID 88, 2021. 